\title{
Bioactive Amines: Aspects of Quality and Safety in Food
}

\author{
Mariana Bacellar Ribas Rodriguez ${ }^{1 *}$, Carla da Silva Carneiro ${ }^{2}$, Marcia Barreto da Silva Feijón ${ }^{3}$ \\ Carlos Adam Conte Júnior ${ }^{1}$, Sérgio Borges Mano ${ }^{1}$
}

${ }^{1}$ Department of Food Technology, Federal Fluminense University, Niterói, Brazil; ${ }^{2}$ Department of Natural Products and Food, Federal University of Rio de Janeiro, Rio de Janeiro, Brazil; ${ }^{3}$ Department of Food Science, Federal Fluminense University, Niterói, Brazil.

Email: ${ }^{*}$ marianabacellar@gmail.com

Received July $5^{\text {th }}, 2013$; revised August $5^{\text {th }}, 2013$; accepted August $12^{\text {th }}, 2013$

Copyright (C) 2014 Mariana Bacellar Ribas Rodriguez et al. This is an open access article distributed under the Creative Commons Attribution License, which permits unrestricted use, distribution, and reproduction in any medium, provided the original work is properly cited. In accordance of the Creative Commons Attribution License all Copyrights (C 2014 are reserved for SCIRP and the owner of the intellectual property Mariana Bacellar Ribas Rodriguez et al. All Copyright (C) 2014 are guarded by law and by SCIRP as a guardian.

\section{ABSTRACT}

Presented in several types of food, bioactive amines are described as organic bases of low molecular weight. They have vasoactive, psychoactive and toxicological characteristics and constitute a potential health risk. The concentration of amines formed in foods depends on the type of microorganisms present, the action of decarboxylase enzymes produced by microorganisms on specific amino acids and favorable conditions for enzymatic activity. The presence of these chemical metabolites has been suggested as a quality indicator in routine analyzes for food production and marketing monitoring. The detection of bioactive amines can be performed by chromatographic methods, fluorometric and enzymatic kits. Bioactive amine formation can be prevented mainly through the adoption of good manufacturing practices, but the industry can also use other methods such as temperature control in the production chain, modified atmosphere packaging and food irradiation. This review aims to address the formation of bioactive amines in foods, emphasizing the formation and classification of these metabolites, aspects related to health, acceptable limits, detection methods and control methods used in the industry to ensure food safety and quality. The success of this approach is linked to the importance of bioactive amines as quality indicators, as well as the discussion on the development of methodologies for determining these substances and discussion of acceptable parameters in food.

\section{KEYWORDS}

Bioactive Amines; Detection Methods; Toxicity; Acceptable Limits; Food Quality

\section{Introduction}

Bioactive amines are low molecular weight organic bases produced by the metabolism of plants, animals and microorganisms [1,2]. These amines can be detected in fresh and processed foods and can be formed by transamination of aldehydes and ketones, hydrolysis of nitrogen compounds, thermal decomposition or by decarboxylation of amino acids [2,3].

Amino acid decarboxylation is the main route of biogenic amine formation and consists of the removal of the $\alpha$-carboxyl group from the amino acid structure forming the correspondent amine [4]. This reaction may occur

\footnotetext{
*Corresponding author.
}

through two biochemical routes: by the action of endogenous decarboxylase enzymes, i.e. enzymes naturally present in food or by exogenous decarboxylase enzymes produced by microorganisms [5,6]. These microorganisms may constitute the characteristic microbiota of the product or may be introduced before, during or after food processing [7]. The concentration and formation of different types of amines are directly related to the nature of the food and type of microorganism present $[8,9]$.

Biogenic amines are present in low concentrations or are not detected in fresh food; however, in food of animal origin such as fish, meat, eggs, cheese and fermented foods, they can be present in high concentration able to induce a chemical poisoning [6]. In the case of fish, his- 
tamine poisoning should be enhanced, historically known as scombroid poisoning for its association with the intake of fish in the Scombridae family which includes tuna and sardines [8].

The accumulation of biogenic amines in food depends on the availability of free amino acids and the presence of microorganisms with decarboxylase activity on amino acids [10]. In addition to the availability of precursor amino acids, amine formation depends on food intrinsic and extrinsic parameters such as: temperature and $\mathrm{pH}$, oxygen tension, availability of carbon sources, presence of vitamins, co-enzymes, concentration of free amino acids and fermentable carbohydrates [11-14]. Thus, the main factors that influence the biosynthesis of these compounds are storage conditions, good manufacturing practices $[15,16]$, the amount of microorganisms with decarboxylase activity $[5,17]$, the quality of the raw material and the availability of free amino acids [18-20].

In this context, the goal of this study is to present a review on the bioactive amines present in food, which included formation, and classification of these metabolites, health related aspects, acceptable limits, detection methods and control methods used in the food industry.

\section{Nomeclature, Classification and Biosynthesis of Bioactive Amines}

According to their biosynthetic pathway, bioactive amines are classified into [4,21-23]:

1) Biogenic: They are formed by bacterial enzymatic decarboxylation of amino acids (histamine, serotonin, tyramine, phenylethylamine, tryptamine, putrescine, cadaverine and agmatine);

2) Natural: Spermine and spermidine are formed "in situ" in the cells as they are required. It is noteworthy that since histamine is stored in mast cells and basophils, it could be classified as biogenic and natural.

With respect to nomenclature, most amines are named according to their precursor amino acids. The most important biogenic amines found in food are: histamine, tyramine, tryptamine, phenylethylamine and cadaverine, the synthesis of which occurs by decarboxylation of the precursor amino acids histidine, tyrosine, tryptophan, phenylalanine and lysine, respectively. In serotonin synthesis, tryptophan is transformed by tryptophan hydroxylase into 5-hydroxytryptophan, which is enzymatically decarboxylated into 5-hydroxytryptamine or serotonin. Tyrosine is the precursor of phenolic amines such as octopamine and dopamine [24]. Cadaverine and putrescine are associated to products under decomposition or putrefaction like spermine and spermidine are associated to seminal fluids where these amines were found for the first time [2,14,23,24].

Biogenic amines can be classified according to the number of amine groups present in the molecule, the chemical structure, the action in the body, and the biosynthetic pathway.

According to the number of amine groups they are classified into [5,21,25]:

1) Monoamines: Tyramine, phenylethylamine.

2) Diamines: Histamine, serotonin, tryptamine, putrescine, cadaverine.

3) Polyamines: Spermine, spermidine and agmatine.

Regarding their chemical structure, they are classified into three major groups: [3,5]:

1) Aliphatic: Putrescine, cadaverine, spermine and spermidine.

2) Aromatic: Tyramine and phenylethylamine.

3) Heterocyclic: Histamine and tryptamine.

Regarding the action in the body, they are classified into [23,26,27]:

1) Vasoactive: Tyramine, tryptamine, phenylethylamine, isoamylamine, histamine and serotonin.

2) Psychoactive: Norepinephrine, serotonin and dopamine.

Regardless their classification, there is a natural mechanism for bioactive amine catabolism. They are oxidized by monoamine oxidases (MAO) and diamine oxidases (DAO). On the other hand, polyamines are oxidized by DAO and polyamine oxidases (PAO) after acetylation reaction [21]. Thus, these amines do not represent a health hazard unless they are consumed in large quantities or if the natural catabolism mechanism of one or more amines is inhibited [2]. In this case, poisoning occurs and thus it is important to determine amine profile and content in food since these substances can trigger toxicological processes $[3,10]$.

\section{Physiological and Toxicological Aspects}

Many amines such as histamine, serotonin, dopamine and tyramine play important roles in maintaining the physiology of living organisms $[4,28]$. Besides, although the bioactive amines spermidine and spermine do not have direct toxicological effects they can potentiate tyramine and histamine toxicity by competing with detoxifying enzymes [29].

The bioactive amines present in food represent a health hazard when consumed in large amount if the natural mechanism for their catabolism is impaired by disease or pharmacological agents or if the individual is genetically deficient [23,30]. Under normal conditions, amines ingested through foods are quickly metabolized by conjugation or by oxidation reactions by amine oxidase enzymes such as monoamine oxidase (MAO), diamine oxidase (DAO), polyamine oxidases (PAO) and N-methyl transferase [21,31-33]. Individuals with respiratory and coronary heart diseases, hypertension problems or vitamin B12 deficiency are at risk because they 
are sensitive to smaller amounts of amines [4,5,34].

People with gastrointestinal problems (gastritis, irritable bowel syndrome, Crohn's disease, gastric and colon ulcers) are also at risk since the activity of the oxidases in their bowels is generally lower than in healthy individuals. People using drugs MAO, DAO and PAO activity inhibitors may also be affected because they prevent amine catabolism [33]. These MAO and DAO inhibitors are used to treat stress, depression, Alzheimer and Parkinson, pulmonary tuberculosis, malaria, panic disorder and social phobia. Histamine is the amine most often related to food poisoning $[10,20,35]$.

\section{Histamine Poisoning}

Histamine poisoning causes an allergic reaction characterized by difficult breathing, vomiting, rash, itching, fever and hypertension. Histamine alone at low levels does not cause poisoning but the presence of other biogenic amines such as putrescine and cadaverine, in concentration five times greater than histamine, enhance its toxicity $[36,37]$. The amines putrescine and cadaverine can potentiate histamine toxic effect, inhibiting DAO enzymes, increasing its transport through the gastrointestinal wall $[38,39]$. The presence of these potentiating substances can explain why, in some cases, spoiled fish and aged cheeses are more toxic than the same amount of histamine ingested alone [14].

Usually bioactive amines are absent or in minimum concentration, below $10 \mu \mathrm{g} / \mathrm{g}$, in fresh foods. However, in fish, fish products, cheese, meat, egg and fermented food they can be present in significant amounts, above 50 $\mu \mathrm{g} / \mathrm{g}$, capable of inducing a chemical intoxication $[4,6,8]$. The symptoms can appear within minutes or up to an hour after ingestion and they include strange taste, headache, dizziness, nausea, facial swelling and flushing, abdominal pain, rapid, weak pulse besides diarrhea. It is worthy to note that once histamine is formed, it is not destroyed by cooking [40]. The concentration of histamine capable of producing poisoning varies in accordance with the susceptibility of each individual. In susceptible individuals, values between 5 and $10 \mathrm{mg} / 100 \mathrm{~g}$ will cause symptoms [23]. Histamine exerts its effects by binding to cell membrane receptors of skin and respiratory, cardiovascular, gastrointestinal and immunologic systems [4]. Clinical signs are more severe in people taking drugs that inhibit histamine detoxifying enzymes in the intestine, in immunosuppressed individuals and individuals that use drugs and/or alcohol and the symptoms of histamine poisoning usually appear shortly after the ingestion of food, lasting approximately 24 hours [41].

\section{Physiological and Toxicological Effects of Other Amines}

High levels of tyramine can lead to poisoning known as cheese reaction caused by the concomitant consumption of food containing this amine [1]. Its intake is associated to headache, decreased movement of the gastrointestinal tract and action on the hunger center promoting hunger satiety sensation [42].

The amines tryptamine, tyramine and phenylethylamine can cause headache, migraine, increased blood pressure due to constriction of the vascular system and increased heart rate [14]. Theses amines are potent vasoconstrictors of both arteries and veins, with tyramine and tryptamine more potent in veins that in arteries, i.e. they are selective vasoconstrictors [43]. Putrescine and cadaverine cause hypotension and bradycardia, besides potentiating the toxicity of other amines [4]. These amines together with tyramine, can potentiate the action of histamine, because they inhibit DAO and N-HMT (N-methyl transferase) increasing its intestinal absorption [35, 38].

Putrescine, cadaverine, tyramine, tryptamine, phenylethylamine, spermine and spermidine are present in fish, aged cheese, red wine and meat products [44].

The amine putrescine has an importance as cell protector against oxidative stress and modulator in gene expression [45].

Cadaverine is a volatile amine, associated to spoiled food. Cadaverine is also associated to halitosis in patients with periodontal disease, and is found in tongue and saliva samples [46].

Polyamines as spermidine and spermine are essential components of living cells, universally occurring in animals and plants and present in most bacteria. These amines are important in regulating nucleic acid function and protein synthesis, as well as in membrane stabilization [14]. These two amines are part of muscles in normal physiological conditions, where they act as hormone or growth factor, essential for cells $[14,47]$. All cells require such amines for growth, regeneration and metabolism [21]. In addition, spermine, spermidine and putrescine, can accelerate the development of tumors, because they are found in tissues with high growing rate, and thus, their ingestion is forbidden to patients under treatment for cancer [23].

Serotonin, formed from the amino acid tryptophan is synthesized in the central nervous system and enteric cells. It acts as neurotransmitter in the central nervous system and it is an endogenous vasoconstrictor involved in the regulation of several physiological functions such as sleep, thirst, hunger, mood and sexual activity, acting on the regulatory system of emotions [48,49].

Agmatine derives from the amino acid arginine and acts as antidepressant [50]. This amine is present in the brain and is widely distributed in tissues and particularly in the stomach and blood, but also in the spinal cord, suggesting that it could be an endogenous modulator of pain regulation, i.e. a neurotransmitter/neuromodulator of 
the central nervous system [50-52].

\section{Toxic Levels}

The toxic levels of bioactive amines in humans are still uncertain and the toxic dose depends on the efficiency of individual metabolism. The toxic dose of histamine is 10 $\mathrm{mg} / 100 \mathrm{~g}$ of food; however susceptible individuals, asthma and ulcer patients are more susceptible to the toxic effects of this amine. The toxic dose of tyramine is 10 $\mathrm{mg} / 100 \mathrm{~g}$ in normal individuals and $6 \mathrm{mg} / 100 \mathrm{~g}$ in those under treatment with monoamine oxidase inhibitors. The toxic dose of phenylethylamine is $3 \mathrm{mg} / 100 \mathrm{~g}$ [2].

Acute and sub-acute toxicity levels were investigated in rats, the approximate values of lethal dose (LD50) for tyramine and cadaverine are higher than $2000 \mathrm{mg} / \mathrm{kg}$ of body weight, and thus their acute toxicity is low. The approximate LD50 for putrescine is $2000 \mathrm{mg} / \mathrm{kg}$, while spermine and spermidine present higher acute toxicity with lethal dose of $600 \mathrm{mg} / \mathrm{kg}$ of body weight. Doses that do not cause adverse effects are $2000 \mathrm{ppm}(180 \mathrm{mg} / \mathrm{kg} /$ day) for tyramine, cadaverine and putrescine; $1000 \mathrm{ppm}$ (83 mg/kg/day) for spermidine and 200 ppm $(19 \mathrm{mg} / \mathrm{kg} /$ day) for spermine $[14,53]$.

In Brazil, the Regulation of Industrial and Sanitary Inspection of Animal Products-RIISPOA does not mention the amine maximum level allowed in products of animal origin [54]. However, MERCOSUR Resolution and the Technical Regulation on the Identity and Quality of Fresh Fish (whole and gutted) establish a maximum level of $100 \mathrm{ppm}(10 \mathrm{mg} / 100 \mathrm{~g})$ of histamine in the muscles of species of the Scombridae, Scomberesocidae, Clupeidae, Coryphaenidae and Pomatomidae families [55,56].

Control of histamine levels was not previously included in the technical norms. The maximum acceptable histamine levels in fish were also established in other countries. In the European Union the regulatory limit is $100 \mathrm{mg} / \mathrm{kg}$ and in USA, the Food and Drug Administration, established a maximum limit of $5 \mathrm{mg}$ histamine/ $100 \mathrm{~g}$ product $(50 \mathrm{ppm})$ at the port and $10 \mathrm{mg}$ histamine/ $100 \mathrm{~g}$ product $(100 \mathrm{ppm})$ in pickled fish for species susceptible to form histamine [41,57]. There are no established standards for cadaverine, putrescine or other biogenic amines with the exception of histamine.

\section{Toxic Analytical Methods for Amine Detection in Food}

From the analytical point of view, bioactive amine detection in food is not simple, because these substances have different chemical structures and variable concentration range which sometimes is very low [58].

Bioactive amine detection and quantification is a complex analytical operation due to factors such as: strong polar character of the compounds, which results in a greater solubility in water rather than in the organic solvents frequently used; absence of intrinsic properties of the compounds, which could enable their detection by usual physico-chemical methods as spectrophotometric, fluorometric or electrochemical methods; sample complexity; low concentration in food; presence of potentially interfering substances such as amino acids with structural similarities with the amines; simultaneous presence of structurally very different amines in the same extract [4].

\subsection{Chromatographic Methods}

The analytical methods are generally based on amine extraction and derivation followed by separation and quantification. Extraction refers to the removal of the amines from the sample (food matrix). It depends on factors such as: type of food and amine present. This step is performed using different solvents according with the sample under study. Amine detection in food matrix is complex, because they are usually present in low concentrations. Besides, most amines do not present absorption in the ultraviolet spectrum nor fluorescence; then a derivation process is needed to increase absorbance and consequently increase detection sensitivity and selectivity $[58,59]$. The reagents most frequently used in amine analysis are: dansyl chloride, fluorescein and orto-phtalaldehyde [60].

Several methods are used for amine separation and quantification in food, among which thin layer chromatography, gas chromatography, high performance liquid chromatography, spectrofluorometry, PCR, ELISA, and electrophoresis.

Chromatographic techniques are the most frequently used, mainly High Performance Liquid Chromatography (HPLC). They provide high resolution, sensitivity and versatility, besides simple sample handling [60]. However, other techniques have been researched aiming at quantifying amines in food in a simple, sensitive and more affordable way.

1) High Performance Liquid Chromatography (HPLC): This analytical method is more advantageous than other methods because it detects other amines along with histamine. Thus, it became the official method for histamine detection in food in several countries. The method enables separations and quantitative analysis of a wide variety of compounds present in various types of samples in a few minutes with high resolution, efficiency and detectability [61]. The European Union (EU) requires the use of HPLC for histamine determination in fishery products with regulation purpose [57]. In Brazil, HPLC is the analytical method for the quantification of histamine and other amines (cadaverine, putrescine, spermidine, spermine) in fish and fishery product control [62]. By establishing this analytical method, Brazil expanded 
its consumer market, exporting fishery products to the EU and other countries that demand histamine quantification by HPLC.

2) Thin layer chromatography: This is a simple, effective and accurate method for bioactive amine separation and detection in all types of food [4]. It is a screening technique used for some time in industries and warehouses and consists in the separation of the components of a mixture through differential migration on a thin layer of adsorbent placed on a plane surface. It is a method of simple execution and low cost [63,64].

3) Gas chromatography: This technique is less expensive and demands less time than high performance liquid chromatography. It analyzes tens of substances in the same sample and has low detection limits. However, if the substance is thermally unstable, it is necessary to obtain a thermally stable derivative which is not always possible. The preparation stage, before analysis, is long and complex. Besides, gas chromatography is not an efficient qualitative technique and many times auxiliary techniques are necessary for reliable identification of the substances present in the sample [65]. The fact that bioactive amines have low molecular weight, high solubility in water and low volatility is another obstacle in using this technique [66]. The aforementioned author reports that it is necessary to perform derivatization of these amines to reduce polarity, improving the selectivity, volatility, sensitivity and separation of these amines. This process is characterized by conducting baths at $60^{\circ} \mathrm{C}$ for about two hours $[67,68]$. Hydrogen is the carrier gas most frequently used [66].

\subsection{Fluorometric Method}

The Technical Regulation on the Identity and Quality of Fresh Fish (whole and gutted) defines the fluorometric method as the official technique for histamine detection in fish in Brazil [56]. Currently, even after the HPLC entered in force, the fluorometric method was not revoked. The fluorometric method consists in histamine extraction with methanol, extract purification on ion exchange resin and subsequent chemical reaction with ortophtalaldehyde, in alkaline medium adding phosphoric acid. The reaction forms a fluorescent compound which is analyzed in a device called fluorometer [69]. Other simple method form was developed to measurement of polyamine as indicator of food decomposition with fluorometer by using 4-(1-Pyrene)butyric acid N-hydroxysuccinimide ester (PSE), it was detected in linear polyamines such putrescine, cadaverine, spermidine and spermine. They also demonstrated here the increase of fluorescence in decomposed sardine and mackerel fish by PSE derivatization just by removing proteins or debris with trichloroacetic acid, which is simpler that ortophtalaldehyde method [70].

\subsection{Enzymatic Kits}

Currently there is an interest for portable, fast screening procedures for field analyses that can be applied for fishery products on the quay, which led to the development of commercial test kits used in Hazard Analysis and Critical Control Point (HACCP) [71]. With the use of HACCP, by many food companies including those that process fishery products, histamine determination was included as critical control point depending on the processed product. The detection of this biogenic amine during food processing led several industries to develop portable kits for histamine analyses which do not require solvents as methanol and can be easily applied in the industries [71].

This is a fast, simple, low cost method for histamine detection capable of promoting accurate results. The kits available in the market are usually classified into qualitative, quantitative or semi quantitative in the range from one to $500 \mathrm{ppm}$ [72].

The tests can be based in two methods, the ELISA method that assesses the direct competition of a substance with the enzyme-linked for a limited number of antibodies, and the chemical colorimetric analysis where an enzyme catalyzes a color change in the reaction with the substrate [72,73].

\section{Bioactive Amines as Quality Index and Control Methods Used in the Food Industry}

Amine formation in foods rich in protein and amino acids may be inherent to the product or due to the action of added microorganisms (starter cultures) and/or contaminants (inadequate sanitary conditions). Thus, amine quantification may be used as quality parameter or index, because it can reflect poor quality of the raw materials and/or sanitary conditions during the manufacture of certain products $[2,14,23,74]$.

The analyses used to determine food quality include sensory and microbiological methods. The first are fast, well accepted but depend on trained panelists and do not detect specific food contamination. On the other hand, microbiological analyses are usually slow, requiring 2 - 5 days to obtain results. For this reason, alternative methods involving chemical changes caused by microbial activity are being studied [75-78].

The presence of chemical metabolites, the biogenic amines, produced by the microbiological spoilage of food is suggested as quality indicator of food in addition to routine analyses $[7,78,79]$. High content of histamine and other amines can be used as quality indicators and also as indicators of potential food poisoning $[1,26]$. This is due to the fact that microbial deterioration can be accompanied by an increase of decarboxylase production [2, 80]. It should be highlighted that these substances are 
reported as heat stable compounds and, cooking or prolonged exposure to heat do not eliminate the toxin [4, 81,82]. Thus, an advantage in using biogenic amines as quality index is that they are thermo resistant and thus, they remain in the food even after heat treatment [23].

Chemical quality indices, through the relation between the bioactive amines histamine, putrescine, cadaverine, spermine and spermidine, were characterized and suggested by some authors for fish and poultry meat $[47,83-$ 85].

Prevention of the formation of bioactive amines in food has been mainly performed through production and storage temperature control, quality of the raw material, good manufacturing practices, use of starter cultures for fermentation, use of enzymes to oxidize amines, use of microbial modeling to assess favorable conditions to delay amine formation, use of adequate packaging techniques and food irradiation [37,68,86,87].

\section{Conclusion}

Bioactive amines are chemical components of a variety of foods, which call attention for different reasons since, and they cause positive biological effects. Being essential for maintaining the physiological activities, they can have adverse effects mainly toxicological in concentrations higher than 100 ppm of histamine. However, more studies to determinate toxic levels to other biogenic amines are necessary. Amine identification and quantification is also an important indicator of the sanitary condition of both the raw material and the final product. Its control is important to reduce damages to the production chain and improve commercial relations with other countries reducing export barriers. Thus, further studies are necessary to establish safety limits for bioactive amines in animal products, vegetables and beverages.

\section{REFERENCES}

[1] B. T. Brink, C. Damink, H. M. L. J. Joosten and J. H. J. H. Veld, "Occurrence and Formation of Biologically Active Amines in Foods," International journal of Food Microbiology, Vol. 11, No. 11, 1990, pp. 73-84. http://dx.doi.org/10.1016/0168-1605(90)90040-C

[2] A. Halász, A. Baráth, L. Simon-Sarkadi and W. Holzapfel, "Biogenic Amines and Their Production by Microorganisms in Food," Trends in Food Science and Technology, Vol. 5, No. 2, 1994, pp. 42-49. http://dx.doi.org/10.1016/0924-2244(94)90070-1

[3] M. Saaid, B. Saad, N. H. Hashim, A. S. M. Ali and M. I. Saleh, "Determination of Biogenic Amines in Selected Malaysian Food,” Food Chemistry, Vol. 113, No. 4, 2009, pp. 1356-1362. http://dx.doi.org/10.1016/j.foodchem.2008.08.070

[4] A. R. Shalaby, "Significance of Biogenic Amines to Food Safety and Human Health,” Food Research International,
Vol. 29, No. 7, 1996, pp. 675-690. http://dx.doi.org/10.1016/S0963-9969(96)00066-X

[5] M. H. Silla-Santos, "Biogenic Amines: Their Importance in Foods," International Journal of Food Microbiology, Vol. 29, No. 2-3, 1996, pp. 213-231. http://dx.doi.org/10.1016/0168-1605(95)00032-1

[6] G. J. Flick and L. A. Granata, "Biogenic Amines in Foods,” In: W. M. Dabrowski and Z. E. Sikorski, Eds., Toxins in Food (Chemical and Functional Properties of Food Components), CRC Press, Boca Raton, 2005, pp. 121-154.

[7] M. Rokka, M. S. Eerola, M. Smolander, H. L. Alakomi and R. Ahvenainem, "Monitoring of the Quality of Modified Atmosphere Packaged Broiler Chicken Cuts Stored in Different Temperature Conditions B. Biogenic Amines as Quality-Indicating Metabolites,” Food Control, Vol. 15, No. 8, 2004, pp. 601-607.

http://dx.doi.org/10.1016/j.foodcont.2003.10.002

[8] C. den Brinker, M. Kerr and C. Rayner, "Investigation of Biogenic Amines in Fish and Fish Products," Victorian Government Department of Human Services: Public Health Division, Austrália, 2002, p. 17.

http://www.health.vic.gov.au/archive/archive2011/foodsafe ty/archive/downloads/histamines_biogenicamines1995.pdf

[9] M. Innocente, M. Biasutti, M. Padovese and S. Moret, "Determination of Biogenic Amines in Cheese Using HPLC Technique and Direct Derivatization of Acid Extract," Food Chemistry, Vol. 101, No. 3, 2007, pp. 1285-1289. http://dx.doi.org/10.1016/j.foodchem.2005.12.026

[10] A. Önal, "A Review: Current Analytical Methods for the Determination of Biogenic Amines in Foods," Food Chemistry, Vol. 103, 2007, pp. 1475-1486. http://dx.doi.org/10.1016/j.foodchem.2006.08.028

[11] S. Bover-cid, M. J. Miguelez-arrizado, B. Backer, W. H. HolzapfeL and M. C. Vidal-carou, "Amino Acid Decarboxylation by Lactobacillus curvatus CTC273 Affected by the $\mathrm{pH}$ and Glucose Availability," Food Microbiology, Vol. 25, No. 2, 2008, pp. 269-277. http://dx.doi.org/10.1016/j.fm.2007.10.013

[12] L. Bunková, F. Bunka, P. Klcovsk, A. V. Mrkvicka, M. Dolezalová and S. Kracmar, "Formation of Biogenic Amines by Gram-Negative Bacteria Isolated from Poultry Skin,” Food Chemistry, Vol. 121, No. 1, 2010, pp. 203206. http://dx.doi.org/10.1016/j.foodchem.2009.12.012

[13] M. B. A. Glória, “Bioactive Amines,” In: H. Hui and L. L. Nollet, Eds., Handbook of Food Science, Technology and Engineering, Taylor \& Francis, New York, Vol. 1, 2005, pp. 13-32.

[14] G. Greif, M. Greifova and J. Karovicova, "Effects of $\mathrm{NaCl}$ Concentration and Initial $\mathrm{pH}$ Value on Biogenic Amine Formation Dynamics by Enterobacter spp. Bacteria in Model Conditions," Journal of Food and Nutrition Research, Vol. 45, No. 1, 2006, pp. 21-29.

[15] T. Komprda, J. Neznalova, S. Standara and S. Bover-Cid, "Effect of Starter Culture and Storage Temperature on the Content of Biogenic Amines in Dry Fermented Sausage Polican,” Meat Science, Vol. 59, No. 3, 2001, pp. 267276. http://dx.doi.org/10.1016/S0309-1740(01)00079-1

[16] P. Kordiovská, L. Vorlova, L. Borkovcova, R. Karpisko- 
va, H. Buchtova, Z. Svobodova, M. Krizer and F. Vacha, "The Dynamics of Biogenic Amine Formation in Muscle Tissue of Carp (Cyprinuscarpio)," Czech Journal of Animal Science, Vol. 51, No. 6, 2006, pp. 262-270.

[17] J. M. Jay, “Frutos do Mar,” In: J. M. Jay, Ed., Microbiologia de Alimentos, Artmed, Porto Alegre, 2005, pp. 119128.

[18] R. Maijala and E. Nurmi, "Influence of Processing Temperature on the Formation of Biogenic Amines in Dry Sausages,” Meat Science, Vol. 39, No. 1, 1995, pp. 9-22. http://dx.doi.org/10.1016/0309-1740(95)80003-4

[19] J. M. Landete, B. D. L. Rivas, A. Marcobal and R. Muñoz, "Updated Molecular Knowledge about Histamine Biosynthesis by Bacteria," Food Science and Nutrition, Vol. 48, 2008, pp. 697-714.

[20] H. C. Chen, Y. R. Huang, H. H. Hsu, C. S. Lin, W. C. Chen, C. M. Lin and Y. H. Tsai, "Dertermination of Histamine and Biogenic Amines in Fish Cubes (Tetrapturusangustirostris) Implicated in a Food-Borne Poisoning," Food Control, Vol. 21, No. 1, 2010, pp. 13-18. http://dx.doi.org/10.1016/j.foodcont.2009.03.014

[21] S. Bardócz, "Polyamines in Food and Their Consequences for Food Quality and Human Health,” Trends in Food Science and Technology, Vol. 6, No. 10, 1995, pp. 341346. http://dx.doi.org/10.1016/S0924-2244(00)89169-4

[22] A. S. Lima and M. B. A. Glória, “Aminas Bioativas em Alimentos,” Boletim da Sociedade Brasileira de Ciência e Tecnologia de Alimentos, Vol. 33, No. 1, 1999, pp. 7079.

[23] P. Kalač, E. Dadáková and T. Pelikánová, “Content of Biogenic Amines and Polyamines in Some Species of European Wild-Growing Edible Mushrooms,” European Food Research Technology, Vol. 230, No. 1, 2009, pp. 163-171. http://dx.doi.org/10.1007/s00217-009-1148-3

[24] M. B. A. Glória, and S. M. Vieira, "Technological and Toxicological Significance of Bioactive Amines in Grapes and Wines,” In: N. Benkeblia, Ed., Food, Global Science Books, ReinoUnido, Vol. 1, No. 2, 2007, pp. 258-270.

[25] M. C. Vidal-Carou, F. Lahoz-Portoles, S. Bover-Cid and A. Marine'-Font, "Ion-Pair High-Performance Liquid Chromatographic Determination of Biogenic Amines and Polyamines in Wine and Other Alcoholic Beverages,” Journal of Chromatography A, Vol. 998, No. 1-2, 2003, pp. 235-241. http://dx.doi.org/10.1016/S0021-9673(03)00610-1

[26] S. Eerola and R. Maijala, "Biogenic Amines: Overview of Food Safety,” In: D. M. L. Morgan, T. Hirvi, G. Dandrifosse, P. Deloyer and A. White, Eds., Health Implications of Dietary Amines: Review of Current Status, Belgium, 2004.

[27] J. D. Cöisson, C. Cerutti, F. Travaglia and M. Arlorio, "Production of Biogenic Amines in Salaminiitalianiallacacciatora PDO,” Meat Science, Vol. 67, No. 2, 2004, pp. 343-349. http://dx.doi.org/10.1016/j.meatsci.2003.11.007

[28] P. Kalač and P. Krausová, "A Review of Dietary Polyamines: Formation, Implications for Growth and Health and Occurrence in Foods," Food Chemistry, Vol. 90, 2005, pp. 219-230. http://dx.doi.org/10.1016/j.foodchem.2004.03.044
[29] S. Moret, D. Smela, T. Populin and L. S. Conte, “A Survey on Biogenic Amine Content of Fresh and Preserved Vegetables,” Food Chemistry, Vol. 89, No. 3, 2005, pp. 355-361.

http://dx.doi.org/10.1016/j.foodchem.2004.02.050

[30] H. Ohta, K. I. Yoza, Y. Takeda and Y. Nogata, “Influence of Storage Temperature on the Polyamine Levels and Ethyleneproduction in Broccoli (Brassica oleracea)," Bioscience, Biotechnology and Biochemistry, Vol. 57, No. 5, 1993, pp. 831-832. http://dx.doi.org/10.1271/bbb.57.831

[31] L. F. Bjeldanes, D. E. Schutz and M. M. Morris, "On the Etiology of Scombroid: Cadaverine Potentiation of Histamine Toxicity in the Guinea-Pig," Food and Cosmetics toxicology, Vol. 16, No. 2, 1978, pp. 157-159. http://dx.doi.org/10.1016/S0015-6264(78)80196-5

[32] M. S. Benedetti, "Biotransformation of Xenobiotics by Amines Oxidades,” Fundamental \& Clinical Pharmacology, Vol. 15, 2001, pp. 75-84. http://dx.doi.org/10.1046/j.1472-8206.2001.00011.x

[33] C. Ortolani and E. A. Pastorello, "Food Allergies and Food Intolerances," Best Practice \& Research Clinical Gastroenterology, Vol. 20, No. 3, 2006, pp. 467-483. http://dx.doi.org/10.1016/j.bpg.2005.11.010

[34] E. Dadáková, M. Krizek and T. Pelikanova, "Determination of Biogenic Amines in Foods Using Ultra-Performance Liquid Chromatography (UPLC)," Food Chemistry, Vol. 116, No. 1, 2009, pp. 365-370. http://dx.doi.org/10.1016/j.foodchem.2009.02.018

[35] L. Lehane and J. Olley, "Review: Histamine Fish Poisoning Revisited,” International Journal of Food Microbiology, Vol. 58, No. 1-2, 2000, pp. 1-37. http://dx.doi.org/10.1016/S0168-1605(00)00296-8

[36] T. Hernández-Jover, M. Izquiermo-Pulido, M. T. VecianaNogués, A. Mariné-Font and M. C. VidaL-Carou, "Biogenic Amine and Polyamine Contents in Meat and Meat Products," Journal of Agricultural and Food Chemistry, Vol. 45, No. 6, 1997, pp. 2098-2102. http://dx.doi.org/10.1021/jf960790p

[37] J. Emborg and P. Dalgaard, "Modelling the Effect of Temperature, Carbon Dioxide, Water Activity and pH on Growth and Histamine Formation by Morganella psychrotolerans," International Journal of Food Microbiology, Vol. 128, No. 2, 2008, pp. 226-233.

http://dx.doi.org/10.1016/j.ijfoodmicro.2008.08.016

[38] S. L. Taylor, “Other Microbial Intoxications,” In: D. O. Cliver, Ed., Foodborne Diseases, Academic Press, San Diego, 1990, pp. 164-168.

[39] M. H. Rapaport, "Dietary Restrictions and Drug Interactions with Monoamine Oxidase Inhibitors: The State of the Art," Journal of Clinical Psychiatry, Vol. 68, No. 8, 2007, pp. 42-46.

[40] G. Campbell-Platt and G. G. May, "Food Science and Technology,” In: G. Platt, Ed., Regulatory Toxicology, Wiley-Blackwell, Iowa, 2009, p. 507.

[41] Food and Drug Administration (FDA), "Fish and Fisheries Products Hazards and Controls Guide," Office of Seafood, Washington DC, 1996.

[42] Food and Agriculture Organization (FAO), "Control de Calidad de Insumos y Dietasacuicolas,” México City, 1994. 
[43] J. Elliot, Y. Berhane and S. R. Bailey, "Effects or Monoamines Formed in the Cecum of Horses on Equine Digital Blood Vessels and Platelets,” American Journal of Veterinary Research, Vol. 64, No. 9, 2003, pp. 11241131. http://dx.doi.org/10.2460/ajvr.2003.64.1124

[44] A. R. Shalaby, "Changes in Biogenic Amines in Mature and Germinating Legume Seeds and Their Behavior during Cooking," Food Nahrung, Vol. 44, No. 1, 2000, pp. 23-27. http://dx.doi.org/10.1002/(SICI)1521-3803(20000101)44: 1<23::AID-FOOD23>3.0.CO;2-B

[45] A. G. Tkachenko, M. R. Pshenichnov and L. I. Nesterova, "Putrescine as a Factor Protecting Escherichia coli against Oxidative Stress,” Microbiology, Vol. 70, No. 4, 2000, pp. 422-428.

[46] S. Goldberg, A. Kozlovsky, D. Gordon, I. Gelernter, A. Sintov and M. Rosenberg, "Cadaverine as a putrefactive Component of Oral Malodor,” Journal of Dental Research, Vol. 76, No. 6, 1994, pp. 1168-1172.

[47] C. M. G. Silva and M. B. A. Glória, "Bioactive Amines in Chicken Breast and Thigh after Slaughter and during Storage at $4 \pm 1{ }^{\circ} \mathrm{C}$ and in Chicken-Based Meat Products," Food Chemistry, Vol. 78, No. 2, 2002, pp. 241-248. http://dx.doi.org/10.1016/S0308-8146(01)00404-6

[48] R. T. Coutts, G. B. Baker and F. M. Pasutto, "Foodstuffs as Sources of Psychoactive Amines and Their Precursors: Content, Significance and Identification,” Journal Advances in Drug Research, Vol. 15, 1986, pp. 169-231.

[49] G. Lenz, "Farmacologia-Compostos Químicos Com Ação Biológica,” 2000. http://www.ufrgs.br/biofis/farmaco.PDF

[50] J. Budni, V. M. Gadotti, M. P. Kaster, A. R. S. Santos and A. L. S. Rodrigues, "Envolvimento dos Canais de k+ no Efeito Antidepressivo da Agmatina no Teste do Nado Forçado,” XXII Reunião Anual da FeSBE (Federação de Sociedades de Biologia Experimental), Águas de Lindóia, 23-26 August 2006.

[51] W. Raasch, S. Regunathan, G. Li and D. J. Reis, “Agmatine, the Bacterial Amine, Is Widely Distributed in Mammalian Tissues,” Life Science, Vol. 56, No. 26, 1995, pp. 2319-2330. http://dx.doi.org/10.1016/0024-3205(95)00226-V

[52] Y. Feng, A. E. Halaris and J. E. Piletz, "Determination of Agmatine in Brain and Plasma Using High-Performance Liquid Chromatography with Fluorescence Detection,” Journal of Chromatography A, Vol. 691, 1997, pp. 277286.

[53] H. P. Til, H. E. Falke, M. K. Prinsen and M. I. Willems, "Acute and Subacute Toxicity of Tyramine, Spermidine, Spermine, Putrescine and Cadaverine in Rats," Food and Chemical Toxicology, Vol. 35, No. 3-4, 1997, pp. 337348. http://dx.doi.org/10.1016/S0278-6915(97)00121-X

[54] Brasil, Ministério da Agricultura, Pecuária e Abastecimento, “Decreto no 30.691 de 29 de Março de 1952, Alterado pelos Decretos no 1255 de 25 de Julho de 1962, no 1.236 de 02 de Setembro de 1994, no 1.812 de 08 de Fevereiro de 1996, no 2.224 de 04 de Junho de 1997 e no 6.385 de 27 de Fevereiro de 2008,” Aprova o novo Regulamento de Inspeção de Produtos de Origem Animal (R.I.I.S.P.O.A.),
Departamento Nacional de Inspeção de Produtos de Origem Animal, Diário Oficial [da] República Federativa do Brasil, Brasília, 2008.

[55] “Mercosul, Resolução GMC no 40—Regulamento Técnico de Identidade e Qualidade de Peixe Fresco (Inteiro e Eviscerado),” XIV GMC, Buenos Aires, 3,VIII, 1994.

[56] Brasil, Ministério da Agricultura, Pecuária e Abastecimento, "Portaria no 185 de 13 de Maio de 1997, Aprova o Regulamento Técnico de Identidade e Qualidade de Peixe Fresco (inteiro e eviscerado),” Diário Oficial [da] República Federativa do Brasil, Brasília, 1997.

[57] União Européia, “No. 2073 de 15 Novembro 2005, Microbiologicalcriteria for Foodstuffs," Commission Regulation (EC), Official Journal of the European Union, Vol. 338, 2005, pp. 1-25.

[58] M. C. Vidal-Carou, M. L. Latorre-Moratalla, S. BoverCid and T. Veciana-Nogués, "Thin-Layer Chromatography for the Identification and Semi-Quantification of Biogenic Amines Produced by Bacteria,” Journal of Chromatography A, Vol. 1216, No. 18, 2009, pp. 4128-4132. http://dx.doi.org/10.1016/j.chroma.2009.02.045

[59] C. Proestos, L. Paul and M. Komaitis, "Determination of Biogenic Amines in Wines by HPLC with Precolumn Dansylation and Fluorimetric Detection," Food Chemistry, Vol. 106, No. 3, 2008, pp. 1218-1224. http://dx.doi.org/10.1016/j.foodchem.2007.06.048

[60] T. Lavizzari, M. T. Veciana-Nogués, S. Bover-Cid, A. Mariné-font and M. C. Vidal-Carou, "Improved Method for the Determination of Biogenic Amines and Polyamines in Vegetable Products by Ion-Pair High-Performance Liquid Chromatography," Journal of Chromatography A, Vol. 1129, No. 1, 2006, pp. 67-72. http://dx.doi.org/10.1016/j.chroma.2006.06.090

[61] I. C. S. F. J. Jardim, H. C. Collins and L. F. L. Guimarães, "Cromatografia Líquida de Alta Eficiência,” In: C. H. Collins, G. L. Braga and P. S. Bonato, Eds., Fundamentos de Cromatografia, Editora da Unicamp, São Paulo, 2006. pp. 274-398.

[62] Brasil, Ministério da Agricultura, Pecuária e Abastecimento, "Instrução Normativa no 25 de 02 de Junho de 2011," Aprova os Métodos Analíticos Oficiais Físico-Químicos para Controle de Pescado e seus Derivados, Diário Oficial [da] República Federativa do Brasil, Brasília, 2011.

[63] D. E. Schutz, G. W. Chang and L. F. Bjeldanes, "Rapid Thin Layer Chromatographic Method for the Detection of Histamine in Fish Products," Journal of the Association of Official Analytical Chemists, Vol. 59, No. 6, 1976, pp. 1224-1225.

[64] L. C. L. Lopes, “Cromatografia em Camada Delgada,” In: C. H. Collins, G. L. Braga and P. S. Bonato, Eds., Fundamentos de Cromatografia, Editora da Unicamp, São Paulo, 2006, pp. 66-86.

[65] P. S. Bonato, “Cromatografia Gasosa,” In: C. H. Collins, G. L. Braga and P. S. Bonato, Eds., Fundamentos de Cromatografia, Editora da Unicamp, São Paulo, 2006, pp. 203-272.

[66] H. Kataoka, "Derivatization Reactions for the Determination of Amines by Gas Chromatography and Their Applications in Environmental Analysis,” Journal of Chro- 
matography A, Vol. 733, No. 1-2, 1996, pp. 19-34. http://dx.doi.org/10.1016/0021-9673(95)00726-1

[67] K. R. Kim, M. J. Paik, J. H. Kim, S. W. Dong and D. H. Jeong, "Rapid Gas Chromatographic Profiling and Screening of Biologically Active Amines," Journal of Pharmaceutical and Biomedical Analysis, Vol. 15, No. 9-10, 1997, pp. 1309-1318. http://dx.doi.org/10.1016/S0731-7085(96)02048-1

[68] J. H. Kim, H. J. Ahn, D. H. Kim, H. S. Yook, H. J. Park and M. W. Byun, "Irradiation Effects on Biogenic Amines in Korean Fermented Soybean Paste during Fermentation," Journal of Food Science, Vol. 68, No. 1, 2003, pp. 80-84.

[69] M. Tavares and R. B. Moreno, "Pescados e Derivados," In: O. Zenebon, N. S. Pascuet and P. Tiglea, Eds., Métodos Físico-Químicos Para Análise de Alimentos, Instituto Adolfo Lutz, São Paulo, 2008. pp. 637-647.

[70] H. Nishikawa, T. Tabata and S. Kitani, "Simple Detection Method of Biogenic Amines in Decomposed Fish by Intramolecular Excimer Fluorescence,” Food and Nutrition Sciences, Vol. 3, 2012, pp. 1020-1026. http://dx.doi.org/10.4236/fns.2012.37135

[71] P. L. Rogers and W. F. Staruszkiewicz, "Performance of Histamine Test Kits for Applications to Seafood," 4th World Fish Inspection \& Quality Control Congress, Vancouver, 26 October 2001.

[72] C. E. Bundac, "Rapid Histamine Test Kit: It’s Your Own Choice,” Seafood Net News, Louisiana, Spring, 2000. http://www2.lsuagcenter.com/seafood/pdfs/NewsSPRIN G2000.pdf

[73] P. L. Rogers and W. F. Staruszkiewicz, "Histamine Test Kit Comparison," Journal of Aquatic Food Product Technology, Vol. 9, No. 2, 2000, pp. 5-17. http://dx.doi.org/10.1300/J030v09n02 02

[74] F. L. Cunha, et al., "Determinação de Aminas Biogênicas em Diferentes Tipos de Queijos por Cromatografia Líquida de Alta Eficiência," Revista do Instituto Adolfo Lutz (Impresso), Vol. 71, No. 1, 2012, pp. 69-75.

[75] S. C. Souza, K. H. Theodoro, E. R. Souza, S. Motta and M. B. A. Glória, "Bioactive Amines in Brazilian Wines: Types, Levels and Correlation with Physic-Chemical Parameters,” Brazilian Archives of Biology and Technology an International, Vol. 48, No. 1, 2005, pp. 53-62.

[76] F. Ozogul and Y. Ozogul, "The Ability of Biogenic Amines and Ammonia Production by Single Bacterial Cultures," European Food Research and Technology, Vol. 225, No. 3-4, 2007, pp. 385-394. http://dx.doi.org/10.1007/s00217-006-0429-3

[77] A. G. Ntzimani, E. K. Paleologos, I. N. Savvaidis and M. G. Kontominas, "Formation of Biogenic Amines and Relation to Microbial Flora and Sensory Changes in Smoked
Turkey Breast Fillets Stored under Various Packaging Conditions at $4{ }^{\circ}$ C," Food Microbiology, Vol. 25, No. 3, 2008, pp. 509-517. http://dx.doi.org/10.1016/j.fm.2007.12.002

[78] R. B. A. Oliveira, W. P. Evangelista, M. J. Sena and M. B. A. Glória, "Tuna Fishing, Capture and Post-Capture Practices in the Northeast of Brazil and Their Effects on Histamine and Other Bioactive Amines," Food Control, Vol. 25, No. 1, 2012, pp. 64-68.

http://dx.doi.org/10.1016/j.foodcont.2011.10.011

[79] R. H. Dainty, "Chemical/Biochemical Detection of Spoilage,” International Journal of Food Microbiology, Vol. 33, No. 1, 1996, pp. 19-33. http://dx.doi.org/10.1016/0168-1605(96)01137-3

[80] T. P. Coultate, J. Frazzon, L. H. B. Soares, L. F. Medina and J. X. Heck, “Alimentos: A Química de Seus Componentes,” Artmed, Porto Alegre, 2004, pp. 267-309.

[81] G. Duflos, "Histamine Risk in Fishery Products,” Bulletin de l'AcademieVeterinaire de France, Vol. 162, No. 3, 2009, pp. 241-246.

[82] V. E. Gonzaga, A. G. Lescano, A. A. Huamán, G. SalmnMulanovic and D. L. Blazes, "Histamine Levels in Fish from Markets in Lima, Perú,” Journal of Food Protection, Vol. 72, No. 5, 2009, pp. 1112-1115.

[83] W. Tapingkae, S. Tanasupawat, K. L. Parkin, S. Benjakul and W. Visessanguan, "Degradation of Histamine by Extremely Halophilicarchaea Isolated from High Salt-Fermented Fishery Products,” Enzyme and Microbial Technology, Vol. 46, No. 2, 2010, pp. 92-99. http://dx.doi.org/10.1016/j.enzmictec.2009.10.011

[84] M. K. Kim, J. H. Mah and H. J. Hwang, "Biogenic Amine Formation and Bacterial Contribution in Fish, Squid and Shellfish,” Food Chemistry, Vol. 116, No. 1, 2009, pp. 87 95. http://dx.doi.org/10.1016/j.foodchem.2009.02.010

[85] L. de la Torre, et al., "Evaluación de Aminas Biogénicas Durante el Almacenamiento en Refrigeración de Carne de Pollo,” Actualidad Avipecuaria, Vol. 6, 2012, pp. 80-83.

[86] M. L. N. E. Dapkevicius, M. J. R. Nout, F. M. Rombouts, J. H. Houben and W. Wymenga, "Biogenic Amine Formation and Degradation by Potential Fish Silage Starter Microorganisms," International Journal of Food Microbiology, Vol. 57, No. 1-2, 2000, pp. 107-114. http://dx.doi.org/10.1016/S0168-1605(00)00238-5

[87] P. Nieto-Arribas, J. M. Poveda, S. Seseña, L. I. Palop and L. Cabezas, "Technological Characterization of Lactobacillus Isolates from Traditional Manchego Cheese for Potential Use as Adjunct Starter Cultures,” Food Control, Vol. 20, No. 12, 2009, pp. 1092-1098. http://dx.doi.org/10.1016/j.foodcont.2009.03.001 